\title{
PENGARUH EKSTRAK KETUMBAR (CORIANDUM SATIVUM) TERHADAP PERUBAHAN TEKANAN DARAH TIKUS PASCA MELAHIRKAN
}

\author{
Vina Nurul utami ${ }^{1}$, Soeharyo Hadisaputro ${ }^{2}$, Sri Rahayu ${ }^{3}$ \\ ${ }^{1}$ Mahasiswa Program Pascasarjana Fakultas Epidemiologi Sains Terapan Universitas \\ Diponegoro Semarang \\ 2 Magister Epidemiologi Fakultas Kedokteran Universitas Diponegoro Semarang \\ 3 Jurusan Kebidanan Politeknik Kesehatan Kemenkes Semarang \\ email: vinanurulutami@yahoo.com
}

\begin{abstract}
Hypertension is the most commont complication during pregnancy and delivery. It causes $5-10 \%$ maternal morbidity and mortality incorporate with bleeding and infection. The Maternal mortality rate caused by hypertension is about 23,95\%. Coriander seeds contain flavonoid which work as antihipypertension and diuretic. This study was to examine coriander extract several dosage on decreasing systolic on post partum rats. An experimental study with randomized pre test and post test controlled group design obvserved 30 white rat Wistar Sp which divided into 5 groups randommly. Sphyngonanometer was applied to measure the blood pressure. Paired t-test, One Way ANOVA, and Repeated Measures ANOVA were administered for data analyses. Results showed that coriander extract on $10 \mathrm{mg} / \mathrm{kg} \mathrm{BB}, 20 \mathrm{mg} / \mathrm{kg}$ weight and $30 \mathrm{mg} / \mathrm{kgweights}$ dosage affected to blood pressure changes on the rat ( $\left(\begin{array}{l}p \\ 0.000\end{array}\right)$, while $20 \mathrm{mg} / \mathrm{kgweights}$ and $30 \mathrm{mg} / \mathrm{kgweight}$ had no significant effects ( $p$ 0.900). It concluded that coriander estract on dosage $30 \mathrm{mg} / \mathrm{kg}$ weight and $20 \mathrm{mg} / \mathrm{kg}$ weight did not effect significantly to decreasing rat's blood pressure. Measuring not only systole pressure was recommended for further studies.
\end{abstract}

Keywords: coriander, blood pressure, female rat, post partum

\begin{abstract}
ABSTRAK
Hipertensi merupakan salah satu komplikasi saat kehamilan, bersalin dan nifas, dan menjadi $5-10 \%$ salah satu penyebab kesakitan dan kematian ibu bersama perdarahan dan infeksi. AKI yang disebabkan hipertensi sebesar 23,95\%. Biji ketumbar mengandung Flavonoid yang memiliki efek antihipertensi dan diuretic Penelitian ini untuk menguji pemberian ekstrak ketumbar beberapa dosis terhadap penurunan tekanan darah sistolik tikus hipertensi pasca melahirkan. Penelitian experimental dengan rancangan randomized pre test and post test controlled group dilakukan untuk mengamati 30 tikus putih betina galur Wistar yang dibagi acak dalam 5 kelompok. Tekanan darah diukur dengan sphyngonanometer. Uji paired t-test, One Way ANOVA dan Repeated Measures ANOVA digunakan untuk analisis data. Hasil penelitian menunjukkan bahwa ada pengaruh ekstrak ketumbar dosis $10 \mathrm{mg} / \mathrm{kg} \mathrm{BB}, 20 \mathrm{mg} / \mathrm{kg}$ BB dan $30 \mathrm{mg} / \mathrm{kg}$ BB terhadap perubahan tekanan darah tikus pasca melahirkan ( 0,000 ). Dosis $20 \mathrm{mg} / \mathrm{kg}$ BB dan $30 \mathrm{mg} / \mathrm{kg}$ BB tidak memberikan perbedaan penurunan yang signifikan $(p 0,900)$. Disimpulkan bahwa ekstrak ketumbar dosis $30 \mathrm{mg} / \mathrm{kg} \mathrm{BB}$ tidak berbeda signifikan dengan dosis $20 \mathrm{mg} / \mathrm{kg}$ BB terhadap penurunan tekanan darah sistolik tikus pasca melahirkan. Mengikutkasertakan pengukuran diastole direkomendasikan untuk penelitian selanjutnya.
\end{abstract}

Kata kunci: ketumbar, tekanan darah, tikus betina, post partum 


\section{PENDAHULUAN}

Hipertensi merupakan salah satu komplikasi yang muncul pada masa kehamilan, bersalin dan nifas, yaitu berkisar $5-10 \%$. Lebih dari sebagian kasus hipertensi gestasional diikuti oleh tanda dan gejala preeklampsia serta menjadi salah satu penyebab kesakitan dan kematian ibu bersama perdarahan dan infeksi. Dari tiga penyebab kematian ibu tersebut, preeklampsia menjadi penyebab kematian ibu yang paling berbahaya diantara lainya (Cunningham, et.al, 2014).

Hipertensi dalam kehamilan yang bermanifestasi klinik menjadi preeklampsia sampai saat ini masih merupakan masalah penting di bidang obstetri. Preeklampsia adalah suatu penyakit dengan tanda-tanda seperti hipertensi, proteinuria, dan edema yang timbul karena kehamilan, penyakit ini umumnya mulai terjadi dalam trimester 3 kehamilan sampai masa nifas (Wiknjosastro, 2009). Preeklampsia diidentifikasi terjadi 3,9\% dalam kehamilan (Cunningham, et.al, 2014). Pada kondisi berat preeklampsi dapat menjadi eklampsi dengan penambahan gejala kejang-kejang, eklampsia dapat muncul sebelum, selama dan setelah proses persalinan. Menurut Alexander (2014) wanita dengan Preeklampsia/eklampsia dapat mengalami eklampsia lagi dalam 48 jam postpartum dan proporsi yang tidak berkembang menjadi eklampsia dalam waktu sebelum 48 jam hanya $10 \%$.

Menurut data yang didapat dari

World Health Organization (WHO) melaporkan pada tahun 2013 terdapat 210/100.000 kelahiran hidup (KH) wanita meninggal akibat komplikasi kehamilan, persalinan dan nifas di seluruh dunia, dan $99 \%$ terjadi di negara berkembang
(UNICEF, 2014; WHO, 2014). Pada negara berkembang kematian ibu disebabkan oleh hipertensi dalam kehamilan sebesar $16 \%$, angka ini lebih tinggi dari perdarahan $13 \%$,abortus $8 \%$ dan infeksi $2 \%$ (Cunningham, et.al, 2014).

Angka Kematian lbu (AKI) di Indonesia pada tahun 2013 menempati peringkat ke lima di seluruh dunia dengan menyumbang 3\% kematian ibu. AKI di Indonesia selalu mengalami kenaikan dimana pada tahun 2010 sebesar 226/100.000 KH, tahun 2011 sebesar 288/100.000 KH dan tahun 2012 sebesar 359/100.000 KH (Kemenkes RI, 2014).

Provinsi Jawa Tengah selama tahun 2014telah mencatat bahwa terdapat 711 kasus kematian ibu (Humas Jateng, 2015). Pada tahun 2013 AKI sebanyak $\quad 118,62 / 100.000 \quad \mathrm{KH}$ mengalami peningkatan jika dibandingkan tahun 2012 sebesar $116,34 / 100.000 \mathrm{KH}$ dan tahun 2011 sebesar 116,01/100.000 KH. Sebesar $57,61 \%$ kematian ibu terjadi pada masa nifas, pada masa hamil sebesar $24,33 \%$ dan masa persalinan sebesar $18,06 \%$. Penyebab AKI paling banyak oleh hipertensi sebesar 23,95\%, kemudian perdarahan sebesar $17,22 \%$, infeksi sebesar $14,04 \%$ dan lain-lain sebesar $54,49 \%$ (Dinkes Provinsi Jateng, 2014).

Masa nifas (Puerperium) adalah masa yang dimulai setelah plasenta keluar dan berakhir ketika alat-alat kandunganya kembali seperti keadaan semula (sebelum hamil) kurang lebih terjadi selama 4-6 minggu (Cunningham, 2014). Ibu nifas dengan preeklampsi berisiko tinggi mengalami komplikasi eklamsia, gagal ginjal akut, perdarahan otak, pembekuan darah intravaskular, 


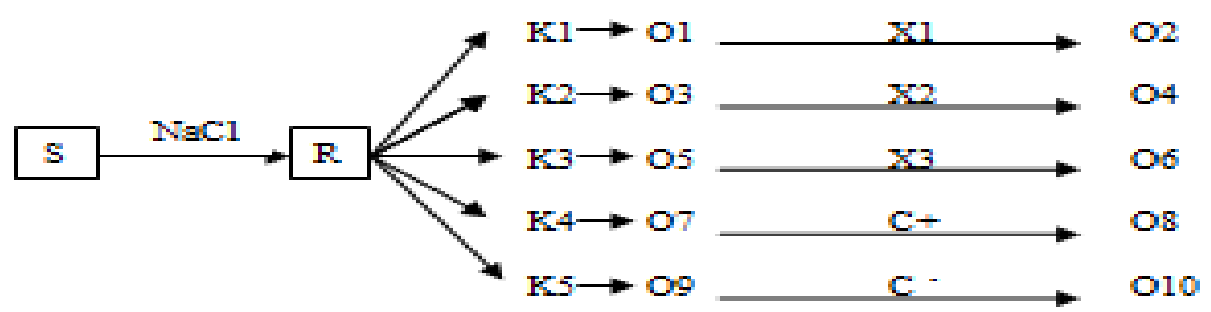

Cambar 3.2 Rancangan Penelitian

Keterangan :

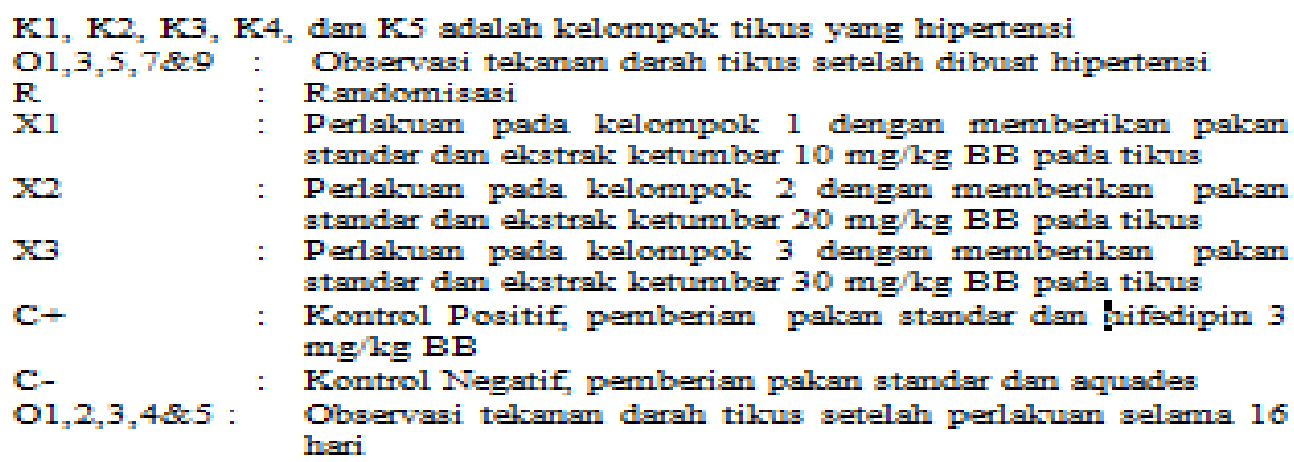

Gambar 1. Gambaran Eksperimen

pembengkakan paru, kolaps pada system pembuluh darah dan HELPP syndrome (Wiknjosastro, 2009). Dampak dari preeklampsi/eklampsi pada janin adalah suplai zat makanan dan oksigen yang dibutuhkan janin berkurang sehingga janin akan terjadi keterlambatan pertumbuhan dalam rahim, prematur, asfiksia, dan kematian (Wiknjosastro, 2009). Setelah memasuki masa nifas, pemberian antihipertensi dan pengawasan tekanan darah harus tetap dilakukan agar mengurangi dampak dari preeklampsia (AHRQ, 2011).

Usaha menurunkan morbiditas dan mortalitas maternal pada masa nifas akibat preeklampsia diperlukan upaya pemberian terapi sesuai program pemerintah dan perkembangan terapi komplementer. Upaya ini memerlukan pengetahuan mengenai dampak preeklampsia pada masa nifas. Sebab, meskipun terminasi kehamilan sudah dilakukan, tetapi dampak dari disfungsi endotel pada seluruh organ tubuh terutama kejadian perpindahan cairan dari intravaskuler ke interstinium serta hipertensi masih terjadi pada masa nifas. Pada preeklampsia diduga terjadi invasi trofoblas yang tidak sempurna saat plasentasi (Cuningham, 2014).

Penggunaan bahan alami sebagai obat tradisional dapat menjadi alternatif pendukung dengan efek samping yang lebih minimal. Salah satu bahan alam yang digunakan untuk menurunkan tekanan darah adalah biji ketumbar. Penelitian tentang ketumbar meunjukkan bahwa salah satu kandungan biji ketumbar adalah senyawa Flavonoid yang memiliki efek menguntungkan terhadap sel-sel mamalia sebagai antihipertensi dan deuretik (Momin, Acharya, \& Gajjar, 2012).

Uji toksisitas dari ekstrak biji ketumbar dilakukan oleh Patel D, dkk, pada 24 ekor tikus dengan dosis 1000 
$\mathrm{mg} / \mathrm{kg} \mathrm{BB}, 3000 \mathrm{mg} / \mathrm{kg} \mathrm{BB}$ dan 5000 $\mathrm{mg} / \mathrm{kg} \mathrm{BB}$, hasil yang didapatkan membuktikkan bahwa ekstrak ketumbar tidak toksik hingga dosis $3000 \mathrm{mg} / \mathrm{kg}$ BB dan tidak ada perubahan perilaku seperti tremor, konvulsi, salivasi maupun lesu (Hosseizodeh, 2011). Penelitian yang dilakukan oleh Jabeen (2008) menunjukkan bahwa biji ketumbar bersifat antihipertensi dan diuretik padatikus dengan dosis $1-30 \mathrm{mg} / \mathrm{km}$ aqueous-methanolic extract ketumbar per intravenous. Ketumbar adalah bahan yang mudah didapat dan murah sehingga perlu dilakukan penelitian tentangekstrak ketumbar terhadap perubahan tekanan darah.

\section{METODE PENELITIAN}

Desain penelitian ini adalah true experimental dengan rancangan randomized pare-test and post-test controlled group design (Campbell in Sastroasmoro, 2011). Hewan yang digunakan dalam penelitian ini adalah tikus galur Wistar yang dibagi dalam 5 kelompok. Prosedur pengelompokan seperti tertera dalam gambar 1.

Teknik analisis data pada penelitian ini adalah pertama dilakukan analisis deskriptif ditampilkan dalam bentuk mean, median, modus dan simpangan baku. Sebelum dianalisis, lebih awal dilakukan uji normalitas dan uji homegenistas pada data. Uji beda antara kelompok dengan paired t-test dan uji parametric menggunakan Repeated Measures Anova menggunakan SPSS soft ware edisi 16.

\section{HASIL PENELITIAN \\ Analisis Univariat}

Tabel 1 menunjukkan nilai ratarata, maksimum, minimum dan standar deviasi berat badan tikus pada masingmasing kelompok perlakuan sebelum dilakukan eksperimen. Data di atas dapat diketahui bahwa berat badan tikus pada masing-masing kelompok cenderung tidak seragam dan menunjukan $p$ yaitu 0,000 .

Tabel 2 menunjukkan nilai tengah, maksimum, minimum dan

Tabel 1. Distribusi Frekuensi Berat Badan Tikus Masing-Masing Kelompok

\begin{tabular}{lllll}
\hline Kel. & Mean & Min & Maks & $\boldsymbol{p}$ \\
\hline K1 & 203,2 & 194 & 213 & 0,000 \\
K2 & 201 & 188 & 213 & \\
K3 & 193,5 & 187 & 198 & \\
K4 & 199,2 & 191 & 209 & \\
K5 & 182,3 & 174 & 190 & \\
\hline
\end{tabular}

Tabel 2. Distribusi Frekuensi Anak Tikus Yang Dilahirkan Masing-Masing Kelompok

\begin{tabular}{lllll}
\hline Kel & Median & Min & Maks & $p$ \\
\hline K1 & 6 & 5 & 7 & 0,0 \\
K2 & 6 & 5 & 7 & 04 \\
K3 & 7 & 6 & 8 & \\
K4 & 7 & 6 & 8 & \\
K5 & 6 & 5 & 7 & \\
\hline
\end{tabular}

standar deviasi anak tikus yang dilahirkan pada masing-masing kelompok perlakuan dan kelompok kontrol. Berdasarkan data di atas dapat diketahui bahwa jumlah anak tikus yang dilahirkan pada masing-masing kelompok cenderung tidak seragam dengan $p$ value yaitu 0,004 .

Tabel 3 menunjukkan nilai ratarata, maksimum, minimum dan standar deviasi tekanan darah pada masingmasing kelompok perlakuan dan kelompok kontrol sebelum diberikan perlakuan. Data di atas dapat diketahui bahwa nilai mean tekanan darah sistolik pada masing-masing kelompok cenderung seragam.

Nilai varian sebelum perlakuan pada K1 berkisar 163.342 sampai dengan 170,32, K2 berkisar 162,85 sampai dengan 177,146, K3 berkisar 
Tabel 3 Distribusi Frekuensi Tekanan

Darah Sistolik Tikus Sebelum dan Sesudah Perlakuan

\begin{tabular}{|c|c|c|c|c|}
\hline Kel. & $\begin{array}{l}\text { Mean } \\
\text { (SD) }\end{array}$ & Min & Maks & $p$ \\
\hline \multicolumn{5}{|c|}{$\begin{array}{l}\text { Sebelum } \\
\text { Perlakuan }\end{array}$} \\
\hline K1 & $\begin{array}{l}166,83 \\
(3,488)\end{array}$ & 163 & 170 & 0,262 \\
\hline K2 & $\begin{array}{l}170 \\
(7,146)\end{array}$ & 162 & 177 & \\
\hline K3 & $\begin{array}{l}168 \\
(4,550)\end{array}$ & 163 & 171 & \\
\hline K4 & $\begin{array}{l}164,67 \\
(7,202)\end{array}$ & 159 & 172 & \\
\hline K5 & $\begin{array}{l}169,7 \\
(3,795)\end{array}$ & 163 & 176 & \\
\hline \multicolumn{5}{|c|}{$\begin{array}{l}\text { Setelah } \\
\text { Perlakuan }\end{array}$} \\
\hline K1 & $\begin{array}{l}146,67 \\
(2,160)\end{array}$ & 144 & 149 & 0,000 \\
\hline K2 & $\begin{array}{l}122,67 \\
(3,983)\end{array}$ & 116 & 128 & \\
\hline K3 & $\begin{array}{l}118,50 \\
(4,593)\end{array}$ & 114 & 125 & \\
\hline K4 & $\begin{array}{l}107 \\
(5,514)\end{array}$ & 101 & 116 & \\
\hline K5 & $\begin{array}{l}171,17 \\
(1,169) \\
\end{array}$ & 170 & 173 & \\
\hline
\end{tabular}

163,45 sampai dengan 172,55 , K4 berkisar 157,47 sampai dengan 171,87 dan K5 berkisar 165,9 sampai dengan 173,5 hal ini menunjukkan bahwa nilai rentan varian antar kelompok tidak jauh berbeda.
Hasil uji dengan menggunakan One Way ANOVA pada tekanan darah pada sebelum perlakuan memiliki $p$ value 0,262 maka Ho diterima dan $\mathrm{Ha}$ di tolak artinya tidak ada perbedaan signifikan antar kelompok.

Setelah diberikan perlakuan nilai Mean tekanan darah pada masingmasing kelompok cenderung tidak seragam. Nilai varian setelah perlakuan pada K1 berkisar 144,51 sampai dengan 148,83, K2 berkisar 118,69 sampai dengan 126,65, K3 berkisar 113,91 sampai dengan 123,09, K4 berkisar 101,49 sampai dengan 112,51 dan K5 berkisar 170,00 sampai dengan 172,34.

Berdasarkan hasil uji One Way ANOVA menunjukan bahwa tekanan darah setelah perlakuan memiliki nilai $p$ 0,000 maka Ho ditolak dan Ha diterima artinya ada perbedaan yang signifikan antar kelompok.

\section{Analisis Bivariat}

Tabel 4 menunjukkan rerata tekanan darah sistolik sebelum dan setelah perlakuan, disertai hasil uji paired t-test antara tekanan darah sebelum dan sesudah perlakuan. Pemberian dosis ketumbar $10 \mathrm{mg} / \mathrm{kg} \mathrm{BB}$ (K1) menunjukkan penurunan rerata tekanan sistolik dari 166,83 menjadi 146,67. Uji paired t-test menunjukkan $p$ 0,000 . Maka Ho ditolak dan Ha diterima, artinya ada perbedaan bermakna tekanan darah sistolik sebelum dan sesudah diberikan ekstrak ketumbar.

Tabel 4. Perbedaan Tekanan Darah Sistolik Sebelum dan Sesudah Perlakuan

\begin{tabular}{llllllll}
\hline $\begin{array}{l}\text { Dosis } \\
\text { (mg/kgBB }\end{array}$ & Mean & Median & Min - Max & Mean & $\begin{array}{c}\text { Setelah } \\
\text { Median }\end{array}$ & Min-Max & p \\
\hline Ketumbar (10) & 166,83 & 167 & $163-170$ & 146,67 & 147,5 & $144-149$ & 0,000 \\
Ketumbar (20) & 170 & 170,5 & $162-177$ & 122,67 & 122,5 & $116-128$ & 0,000 \\
Ketumbar (30) & 168 & 169 & $163-171$ & 118,50 & 117,5 & $114-125$ & 0,000 \\
Nifedipin (3) & 167,67 & 164 & $159-172$ & 107 & 106 & $101-116$ & 0,000 \\
Pakan Standar & 169,7 & 168,5 & $162-177$ & 171,17 & 122,5 & $116-128$ & 0,253 \\
\hline
\end{tabular}


Pada pemberian ekstrak ketumbar $20 \mathrm{mg} / \mathrm{kgBB} \quad(\mathrm{K} 2)$, rerata tekanan sistolik tikus turun dari 170 menjadi 122,67. Hasil uji menunjukkan $p$ 0,000 . Ho ditolak dan Ha diterima, artinya ada perbedaan yang bermakna tekanan darah sistolik sebelum dan sesudah diberikan ekstrak ketumbar 20 $\mathrm{mg} / \mathrm{kg} \mathrm{BB}$.

Pada dosis ketumbar $30 \mathrm{mg} / \mathrm{kg}$ BB (K3) tekanan sistolik turun dari 168 menjadi 118,50. Hasil uji statistik didapatkan $p \quad 0,000$. Ho ditolak artinya ada perbedaan yang bermakna tekanan darah sistolik sebelum dan sesudah diberikan ekstrak ketumbar $30 \mathrm{mg} / \mathrm{kg} \mathrm{BB}$.

Pada kontrol positif, pemberian

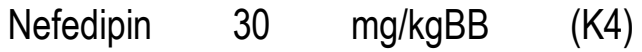
menunjukkan penurunan tekanan sistolik dari 167,67 menjadi 107. Uji statistik memperoleh $p \quad 0,000$. Ho ditolak dan $\mathrm{Ha}$ diterima, artinya ada perbedaan yang bermakna tekanan darah sistolik sebelum dan sesudah diberikan nifedipin $30 \mathrm{mg} / \mathrm{kg} \mathrm{BB}$.

Sedangkan pada kondisi pemberian pakan dan minum standar (K5), rerata tekanan darah sistolik tikus justru mengalami peningkatan dari 169,71 menjadi 71,17 . Ho diterima dan Ha ditolak, artinya tidak ada perbedaan yang bermakna tekanan darah sistolik pada pengamatan pertama dengan kedua pada kelompok kontrol negatif.

Tabel hasil uji Tukey menunjukkan selisih tekanan darah sistolik setelah perlakuan antara kelompok perlakuan dengan kelompok kontrol yaitu K1 memiliki tekanan darah sistolik lebih tinggi dari K2 sebesar 10,42, tekanan darah sistolik K1 lebih tinggi dari K3 sebesar 13,50, tekanan darah sistolik K1 lebih tinggi dari K4 sebesar 20,92 dan lebih rendah dari K5 sebesar 13,42. Tekanan darah sistolik K2 lebih tinggi dengan selisih sedikit dari $\mathrm{K} 3$ sebesar 3,08, tekanan darah sistolik K2 lebih tinggi dari K4 sebesar 10,50 dan lebih rendah dari K5 sebesar 23,83. Tekanan darah sistolik K3 lebih tinggi dari K4 sebesar 7,42 dan lebih rendah dari $\mathrm{K} 5$ sebesar 26,92 sedangkan selisih antara K4 dengan K5 adalah lebih rendah 34,35 .

Tabel 5 Perbedaan Perubahan Tekanan Sistolik antara Kelompok Perlakuan dengan Kelompok Kontrol

\begin{tabular}{lll}
\hline $\begin{array}{l}\text { Pasangan } \\
\text { Perlakuan }\end{array}$ & $\begin{array}{l}\text { Perubahan } \\
\text { Mean }\end{array}$ & $\boldsymbol{p}$ \\
\hline K1 vs K2 & 10,42 & $0.000^{*}$ \\
K1 vs K3 & 13,50 & $0.000^{*}$ \\
K1 vs K4 & 20,92 & $0.000^{*}$ \\
K1 vs K5 & $-13,42$ & $0.000^{*}$ \\
K2 vs K3 & 3,08 & 0.900 \\
K2 vs K4 & 10,50 & $0.000^{*}$ \\
K2 vs K5 & $-23,83$ & $0.000^{*}$ \\
K3 vs K4 & 7,42 & $0.000^{*}$ \\
K3 vs K5 & $-26,92$ & $0.000^{*}$ \\
K4 vs K5 & $-34,33$ & $0.000^{*}$ \\
\hline Ket: ${ }^{*}$ signifikan &
\end{tabular}




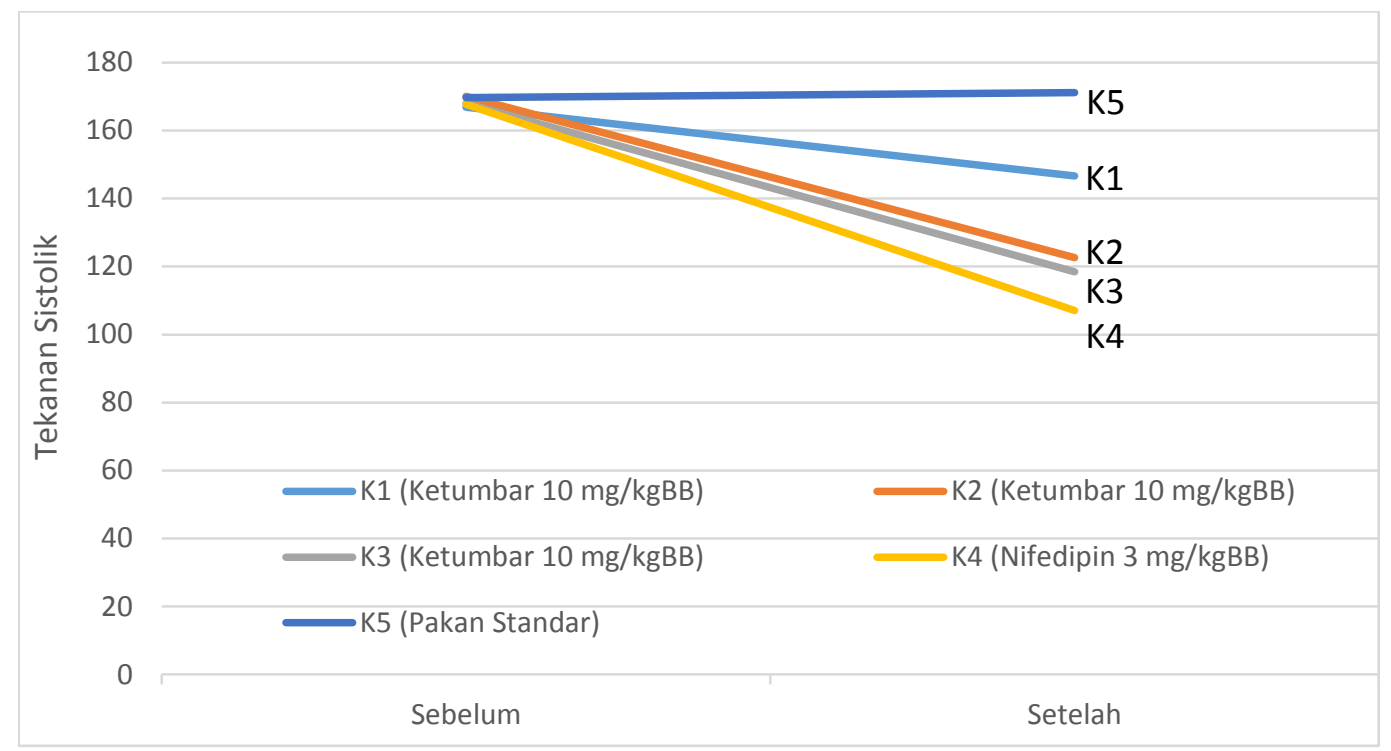

Grafik 2 Rata-Rata Penurunan Tekanan Darah Sistolik Sebelum dan Setelah Perlakuan antara Kelompok Perlakuan dan Kelompok Kontrol

Berdasarkan hasil uji Repeated Measures ANOVA di peroleh $p$ value pada semua pasangan kelompok perlakuan memiliki $p$ value sebesar $0,000 \quad(<0,05)$ yang memiliki makna terdapat perbedaan yang signifikan antara dua kelompok kecuali pada K2 (ekstrak ketumbar $20 \mathrm{mg} / \mathrm{kg} \mathrm{BB}$ ) dengan K3 (ekstrak ketumbar $30 \mathrm{mg} / \mathrm{kg} \mathrm{BB}$ ) memiliki $p$-value $0,900 \quad(>0,05)$ hal tersebut menunjukkan bahwa diantara perlakuan pemberian ekstrak ketumbar dosis $20 \mathrm{mg} / \mathrm{kg}$ BB dengan ekstrak ketumbar $30 \mathrm{mg} / \mathrm{kg}$ BB tidak ada perbedaan signifikan.

Grafik 2 menunjukkan bahwa penurunan tekanan darah sistolik dapat dilihat secara jelas, pada garis biru muda memperlihatkan tekanan darah sistolik kelompok kontrol yang tidak mengalami penurunan bahkan cenderung mengalami peningkatan. Garis biru tua memperlihatan tekanan darah sistolik pada kelompok yang diberi ekstrak ketumbar $10 \mathrm{mg} / \mathrm{kg}$ BB mengalami penurunan tekanan darah sistolik dan jarak dengan garis biru muda terpisah relatif jauh.

Garis merah memperlihatkan tekanan darah sistolik pada kelompok yang diberi ekstrak ketumbar $20 \mathrm{mg} / \mathrm{kg}$ BB mengalami penurunan tekanan darah sistolik yang signifikan dan jarak dengan garis biru muda terpisah relatif jauh. Garis hijau memperlihatan tekanan darah sistolik pada kelompok yang diberi ekstrak ketumbar $30 \mathrm{mg} / \mathrm{kg}$ BB mengalami penurunan tekanan darah sistolik signifikan, jarak dengan garis biru muda terpisah relatif jauh dan jarak dengan garis ungu relatif dekat. Garis ungu memperlihatan tekanan darah sistolik pada kelompok kontrol positif yang diberi nifedipin $3 \mathrm{mg} / \mathrm{kg} \mathrm{BB}$

\section{PEMBAHASAN}

\section{Analisis Univariat}

Tikus putih laboratorium merupakan karakteristik genetik yang unik, mudah berkembang biak, murah, mudah untuk mendapatkannya serta memiliki ekor yang lebih panjang dibandingkan mencit sehingga mudah 
diukur tekanan darahnya dalam penelitian ini. Karakteristik tikus berdasarkan berat badan yang tersaji pada tabel 1 menunjukkan p 0,000 artinya berat badan tikus betina galur wistar pada masing-masing kelompok berbeda signifikan akan tetapi berat badan rata-rata tikus pada masingmasing kelompok sesuai dengan teori bahwa tikus betina memiliki beratbadan antara 225-325 gram (Muliani, 2011).

Kararakteristik jumlah anak tikus lahir hidup yang tersaji pada tabel 3 memiliki $p$ 0,004 artinya ada perbedaan signifikan antar kelompok dengan nilai tengah $6,6,7,7$ dan 6 walaupun secara nilai statistik terdapat perbedaan signifikan antar kelompok akan tetapi jumlah anak tikus yang dilahirkan sesuai dengan teori bahwa tikus putih beranak sejumlah 6-9 ekor dan hamil 4-5 kali dalam setahun (Muliani, 2011).

Pengukuran tekanan darah sistolik tikus sebelum perlakuan tersaji dalam tabel 3 menunjukkan bahwa $p$ 0,262 artinya tidak terdapat perbedaan signifikan antar kelompok. Tikus putih setelah diaklimasikan selama 7 hari dipersiapkan dalam keadaan hipertensi sebelum diberikan perlakuan pemberian ekstrak ketumbar dengan cara diberikan $\mathrm{NaCl}$ 1\% BB per oral sejak mulai usia hamil pertama sampai usia hamil 7 hari, hal ini sesuai dengan penelitian yang dilakukan sebelumnya oleh Lailani tahun 2013 menyatakan bahwa diet tinggi garam menyebabkan peningkatan yang bermakna pada tekanan darah tikus Wistar betina, baik tekanan darah sistolik, tekanan darah diastolik maupun tekanan arteri rata-rata.

Karakteristik tekanan darah sistolik setelah perlakuan pemberian ekstrak ketumbar beberapa dosis per oral yang tersaji dalam tabel 4 menunjukkan $p \quad 0,000$ artinya ada perbedaan yang signifikan antar kelompok. Hasil penelitian ini sejalan dengan penelitian yang pernah dilakukan oleh Jabeen (2009) yang mengatakan bahwa biji ketumbar bersifat antihipertensi dan diuretik pada tikus dengan dosis 1-30 mg/kg aqueousmethanolic extract ketumbar per intravenous (Jabeen, 2008).

\section{Analisis Bivariat}

Hasil analisis bivariat yang telah dilakukan pada penelitian ini sebelum dan sesudah diberikan ekstrak ketumbar dosis $10 \mathrm{mg} / \mathrm{kg}$ BB memiliki $p$ sebesar 0,000 , dosis $20 \mathrm{mg} / \mathrm{kg}$ BB sebesar 0,000 dan dosis $30 \mathrm{mg} / \mathrm{kg}$ BB sebesar 0,000 hal ini menunjukkan bahwa penurunan kadar tekanan darah sistolik tikus yang terjadi pada penelitian ini karena ada peranan yang positif dari tindakan pemberian ekstrak ketumbar terhadap tikus pasca bersalin yang mengalami peningkatan tekanan darah, meskipun ekstrak ketumbar yang diberikan per oral dosis $10 \mathrm{mg} / \mathrm{kg} \mathrm{BB}, 20 \mathrm{mg} / \mathrm{kg}$ BB dan 30 $\mathrm{mg} / \mathrm{kg} \quad \mathrm{BB}$ berpengaruh signifikan terhadap perubahan tekanan darah tikus putih akan tetapi pada tiap dosis memiliki besar efek yang berbeda dalam penururnan hipertensi, hal tersebut dapat dilihat dari nilai rata-rata tekanan darah setelah perlakuandan beda selisih terhadap kelompok kontrol. Ekstrak ketumbar dosis $30 \mathrm{mg} / \mathrm{kg} \quad \mathrm{BB}$ berpengaruh terhadap penurunan tekanan darah lebih besar dibanding dosis $10 \mathrm{mg} / \mathrm{kg}$ BB dan $20 \mathrm{mg} / \mathrm{kg}$ BB serta memiliki efek yang hampir sama dengan pemberian nifedipin $3 \mathrm{mg} / \mathrm{kg}$ BB dengan rata-rata tekanan darah sistolik tikus sebesar 118,5 mmHg. Ekstrak ketumbar dosis $20 \mathrm{mg} / \mathrm{kg}$ BB memiliki efek penurunan tekanan darah yang signifikan dan nilai rata-rata tekanan darah sistoliknya adalah 122,6 mmHg 
hal ini menunujukkan bahwa tekanan darah sistolik tikus kembali normal sedangkan dosis $10 \mathrm{mg} / \mathrm{kg}$ BB memiliki nilai yang signifikan dalam penurunan tekanan darah sistolik tikus akan tetapi nilai rata-ratanya adalah $146,67 \mathrm{mmHg}$ hal ini menunjukkan bahwa tikus masih mengalami hipertensi.

Perbandingan antar kelompok intervensi dan kelompok kontrol dimaksudkan untuk mengetahui kelompok perlakuan mana yang paling berpengaruh dalam penurunan tekanan darah sitolik tikus betina galur wistar pasca melahirkan dengan melihat selisih kemampuan menurunkan tekanan darah sistolik antara kelompok perlakuan dengan kelompok kontrol. Delta mean antara dua kelompok menunjukkan bahwa kelompok perlakun K1, K2 dan K3 jika dibandingkan dengan kelompok kontrol maka memiliki nilai lebih besar dalam menurunkan tekanan darah sistolik, akan tetapi kelompok perlakuan $\mathrm{K} 1$, K2 dan K3 jika dibandingkan dengan kelompok kontrol positif dimana tikus diberikan nifedipin $30 \mathrm{mg} / \mathrm{kg} \mathrm{BB}$ maka di peroleh bahwa tekanan darah sistolik pada kelompok perlakuan masih lebih tinggi dibandingkan kelompok kontrol positif, nifedipin bekerja dengan cara menghambat jumlah kalsium yang menuju sel otot halus pada dinding pembuluh darah dan jantung sehingga terjadi vasodilatasi pada pembuluh darah dan menurunkan tekanan darah.

Penurunan tekanan darah sistolik mengiindikasikan secara objektif penanganan hipertensi pada tikus pasca bersalin dengan pemberian ekstrak ketumbar. Perbedaan efek penurunan tekanan darah sistolik berbeda tergantung pada dosis yang diberikan. Berdasar teori farmakokinetik bahwa pemberian obat secara oral jika setelah mencapai titik puncak absorpsi maka akan terjadi perubahan dari fase absorpsi ke fase distribusi, metabolisme dan ekskresi. Kadar zat aktif dalam plasma darah setelah mencapai keseimbangan antara semua cairan dalam tubuh menunjukkan hubungan yang baik antara kadar zat aktif dalam plasma dengan efek terapi. Hal ini dapat dikatakan bahwa hubungan bioavibilitas dan efektivitas terjadi berdasarkan asumsi intensitas dan durasi respon farmakologik obat berkaitan antara kadar dan durasi obat aktif dalam darah atau sirkulasi sistemik.

Mekanisme kerja senyawa aktif ketumbar sebagai agen hipotensi adalah terdapat senyawa flavonoid, kandungan flavonoid dikaitkan dengan efek perlindungan terhadap fungsi endotel dan menghambat agregasi platelet, sehingga dapat menurunkan resiko penyakit jantung koroner, penyakit kardiovaskuler. Flavonoid memiliki efek hipotensi dengan mekanisme menghambat aktivitas ACE, serta sebagai diuretic (Ahjun, et.al., 2011).

Flavoniod dapat menghambat ACE . diketahui ACE memegang peran dalam pembentukan angitensin II yang merupakan salah satu penyebab hipertensi. Angiotensin II menyebabkan pembulah darah menyempit, yang dapat menaikan tekanan darah. ACE inhibitor menyebabkan pembuluh darah melebar sehingga darah lebih banyak mengalir ke jantung, mengakibatkan penurunan tekanan darah. Selain itu flavonoid dapat meningkatkan urinasi dan pengeluaran elektrolit, yang mana berfungsi layaknya kalium, yaitu mengabsorpsi cairan ionion natrium seperti kalium yangada di dalam intraseluler memasuki tubulus ginjal. Glomerular Filtration Rate (GFR) yang tinggi akibat adanya aktivitas (Panjaitan \& Bintang, 2014; Beevers, Lip, 
O'brien, 2006; Ismarani, Pradono, Darusman, 2011).

Hipertensi yang terjadi dari masa kehamilan akan tetap berpengaruh sampai masa nifas, hal ini sangat berbahaya bagi ibu karena dapat menjadi eklamsia dalam 24 jam post partum, hipofibrinogemia, hemolysis, perdarahan otak, kelainan mata, edema paru-paru, nekrosis hati, gagal jantung hingga syok dan kematian dan sindroma HELLP ( haemolysis, elevated liver enzymes and low platelet), komplikasi lain (lidah tergigit, trauma, fraktur, pneumonia aspirasi dan DIC (Disseminate Intravascular Coagulation) (Wiknyosusastro, ) Perubahan pokok yang didapatkan pada preeklampsia adalah spasmus pembuluh darah disertaidengan retensi garamdan air. Bila dinggap bahwa spasmus arteriola suka ditemukan di seluruh tubuh, maka mudah dimengerti bahwa tekanan darah yang meningkat tampaknya merupakan usaha mengatasi kenaikan tahanan perifer. ${ }^{1}$ Pasca bersalin volume darah ibu relatif akan bertambah. Keadaan ini akan menyebabkan beban pada jantung. Tubuh akan menyerap kembali sejumlah cairan yang berlebihan setelah persalinan. Pada sebagian besar ibu, hal ini akan mengakibatkan pengeluaran urine dalam jumlah besar, terutama pada hari pertama karena diuresis meningkat (Cunningham, 2014).

\section{KETERBATASAN}

Penelitian ini membutuhkan waktu yang cukup lama karena kegagalan tikus untuk hamil cukup tinggi. Pengukuran tekanan darah tikus putih menggunakan sphyngonanometer hanya dapat mengukur tekanan darah sistolik.

\begin{abstract}
KESIMPULAN
Berdasarkan hasil penelitian perlakuan pemberian ekstrak ketumbar yang dilakukan selama 16 hari pada pada tikus hamil sampai pasca bersalin di Laboratorium PSPG UGM maka dapat diambil kesimpulan bahwa: 1) Pemberian ekstrak ketumbar beberapa dosis (10 $\mathrm{mg} / \mathrm{kg} \mathrm{BB}, 20 \mathrm{mg} / \mathrm{kg}$ BB dan $30 \mathrm{mg} / \mathrm{kg}$ BB) berpengaruh terhadap tekanan darah sistolik tikus pasca melahirkan. 2) Ekstrak ketumbar dosis $20 \mathrm{mg} / \mathrm{kg}$ BB dan $30 \mathrm{mg} / \mathrm{kg}$ BB tidak memiliki perbedaan yang signifikan dalam menurunkan tekanan darah sistolik tikus pasca melahirkan akan tetapi lebih efektif dibandingkan dengan dosis 10 $\mathrm{mg} / \mathrm{kg} \mathrm{BB}$.
\end{abstract}

\section{SARAN}

Penelitian lebih lanjut dilakukan pengukuran tekanan darah tidak hanya sistolik akan tetapi juga diastolik dan dosis yang lebih besar dimana pada penelitian ini hanya pengukuran tekanan darah sistolik saja. Penelitian lebih lanjut dilakukan kepada manusia dimana pada penelitian ini dilakukan kepada tikus laboratorium. Penelitian lebih lanjut mengenai uji toksisitas ekstrak ketumbar kepada manusia yang diberikan secara peroral, dimana pada penelitian sebelumnya dilakukan pada tikus. Penelitian lebih lanjut mengenai penggunaan sediaan dalam bentuk sederhana, misal kaplet bukan ekstrak ketumbar. Hal ini untuk memudahkan pemberian terapi. Penelitian lebih lanjut menggunakan perbandingan kontrol positif obat antihipertensi yang bersifat ACE inhibitor misalnya captopril dan bersifat antidiuretik misalnya furosemide, hal ini agar sesuai dengan mekanisme aksi flavonoid dalam ketumbar. 
Penelitian lanjut mengenai pengaruh kandungan aktif pada ketumbar terhadap fetus dan ibu hamil, dimana pada penelitian ini tidak dilakukan.

\section{DAFTAR PUSTAKA}

Adi, L.T., 2008, Tanaman Obat dan Jus. PT.Agromedia, Tangerang

Ahjun,V., Pandeyan, S.N., Yadavi, S.K., Singh,S., Soni,P., 2011, Review On Coriandum Sativum (Linn.): An Ayurvedic Medicinal Herb Of Happiness. Journal of Advance in Pharmacy and Healtcare Research, vol. 1, issue 3.

AHRQ. (2011). WHO recommendations for prevention and treatment of pre-eclampsia and eclampsia. Retriefed 8 April 2011 from : http://www.guideline.gov/content.a spx?id=39384 .

Alexander, JM, Cunningham FG: Management. In Tylor RN, Robert, Cunningham FG (eds). (2014, )Chesley's. Hypertensive Disorders in Pregnancy. Amsterdam: Academic Press.

Beevers G, Lip GYH, O'brien, E. (2006). $A B C$ of hypertension: the phathopysiology of hypertension. Biomedical Journal,322:912-916.

Cunningham FG, Leveno KJ, Bloom SL, Hauth JC, Rause DJ, Spancy CY. 2014. Williams Obstetrics 24 ed. New York: Mc Graw Hill.

Dinkes Provinsi Jateng. 2014. Profil Kesehatan Jawa Tengah Tahun 2013. Retrieved 8 April 2015 from http://dinkesjatengprov.go.id/v201 4/Document/profil2013/\#p=19.

Dinkes Kabupaten Pemalang. 2014. Profil Kesehatan Kabupaten
Pemalang 2013. Pemalang : Dinkes Kabupaten Pemalang

Hosseizodeh, H. (2011) anticonvulsant effect of Coriandum Ssativum $L$. seed extract in mice. Retrieved 20 Mei 2015 from http://www.sid.ir/En/VEWSSID/J_p df/86920000405.pdf.

Humas Jateng. (2015). Puskesmas garda turunkan AKI dan AKB. Retrived 8 April 2015 from http://www.jatengprov.go.id/id/berit a-utama/puskesmas-gardaturunkan-aki-dan-akb.

Ismarani, Pradono, DI., Darusman, LK. (2011). Mikro enkapsulasi ekstrak formulan pegagan-kumis kucingsambiloto sebagai inhibitor Angiotensin I converting enzyme secara in vitro. CEFARS Jurnal Agribisnis dan Pengembangan Wilayah, 3(1): 11-24

Jabeen, Q. (2008). Coriander fruit exhibits gut modulatory, blood pressure lowering and diuretic activities. Retrieved 20 Mei 2015 from

http://ecommons.aku.edu/cgi/view content. cgi?article $=1060 \&$ context $=$ pakistan_fhs_mc_bbs .

Kemenkes RI. (2011). Peraturan menteri kesehatan republik indonesia nomor 2562 tahun 2011. Retrieved 8 April 2015 from http://www.depkes.go.id/download s/PERATURAN_MENTERI_KESE HATAN_JUKNIS_JAMPERSAL.pd $f$

Kemenkes RI. (2014). Profil kesehatan Indonesia tahun 2013. Retrieved 8 April 2015 from http://www.depkes.go.id/resources /download/pusdatin/profil- 
kesehatan-indonesia/profil-

kesehatan-indonesia-2013.pdf .

Momin, AH., Acharya, S and Gajjar A. (2012). Review of advances in phytopharmacology coriandrum sativum 2012. Retrieved 20 Mei 2015 from http://www.ijpsr.com/V315/2\%20Vo $1 . \% 203, \% 20$ lssue $\% 205, \% 20$ May $\%$ 202012,\%20IJPSR482,\%20Paper\%202.pdf

Muliani, H. (2011). Pertumbuhan mencit (Mus Musculus L.) setelah pemberian biji jarak pagar (Jatropha curcas L.). Jurnal Anatomi Fisiologi, 19(1).

Panjaitan, RGP., Bintang, M. (2014). Peningkatan kandunga kalium Urin setelah Pemberian Ekstrak Sari buah Belimbing Manis (Avverhoa Carambola). Jurnal Veteriner, 15(1): 108-13.

Sastroasmoro, S., Ismael, S. (2011). Dasar-dasar metodologi penelitian edisi 4. Jakarta: Sagung Seto.

Unicef. 2014. Maternal mortality has declined steadily since 1990, but not quickly enough to meet the MDG target. Available from http://data.unicef.org/maternalhealth/maternalmortality\#sthash.9iwJps4j.dpuf diakses tanggal 8 April. 2015

WHO. (2014). Maternal mortality. Retrieved 8 April 2015 from http://www.who.int/mediacentre/fa ctsheets/fs348/en/

Wiknjosastro. (2009). IImu kebidanan. Jakarta: PT Bina Pustaka Sarwono Prawirohardjo. 